\title{
ANALISIS PEMAKAIAN PENDAPAT FIQH MAZHAB AL-SHĀFI'I ' DALAM PANDANGAN HUKUM HALAL HARAM ADITIF MAKANAN DI MALAYSIA
}

\section{Analysis on the Application of Shafi'ite Views in Determining Rulings on Halal Additives in Malaysia}

\author{
Ridzwan Ahmad* \\ Tuan Sidek Tuan Muda** \\ Nor Fahimah Mohd Razif ${ }^{* * *}$
}

\begin{abstract}
Food additives are among the important items used in the current food industry. These are substances added to food for various purposes such as preservation, giving flavor, retaining nutritional values, maintaining freshness and safety, increasing affordability and convenience and improving taste or appearance. As science and technology develop rapidly in producing different additives with multiple uses, there is a need to determine rulings on halal. Hence, this study is conducted to analyze the extent to which the Shafi'ite views are applied in the determination of halal rulings on additives in Malaysia. This study adopts a qualitative method
\end{abstract}

\footnotetext{
* Senior Lecturer, Department of Fiqh and Usul, Academy of Islamic Studies, University of Malaya, ridzwan@um.edu.my

** Postgraduate Student, Department of Fiqh and Usul, Academy of Islamic Studies, University of Malaya, sidek@ump.edu.my

*** Senior Lecturer, Department of Fiqh and Usul, Academy of Islamic Studies, University of Malaya, norfahimah@um.edu.my
} 
whereby data collection is taken from various written materials related to halal rulings in Malaysia, scholars' opinions and other related documents. The results of the analysis show that the Shafi'ite views greatly influenced halal rulings on additives in Malaysia. However, in certain cases, the views of other fiqh schools are also applied for the reason of mașlahah. The domination of Shafi'ite views on halal additives in Malaysia demonstrates how local wisdom has been manifested and applied wisely by Malaysian Muslim scholars.

Keywords: Halal, Malaysia, Food Additives, Shafi'ite, Islamic Rulings.

\section{PENDAHULUAN}

Aditif makanan ialah apa-apa bahan yang selamat dimakan dan dimasukkan dengan sengaja ke dalam makanan dalam kuantiti yang sedikit bagi apa-apa tujuan teknologi yang akan mempengaruhi ciri-ciri makanan tersebut ${ }^{1}$. Ia mempengaruhi kualiti penyimpanan, tekstur, konsistensi, rupa, bau, rasa, kealkalian atau keasidan makanan, ataupun secara tidak langsung semasa pemprosesan, penyimpanan atau pembungkusan ${ }^{2}$.

Penggunaan aditif makanan telah menjadi amalan biasa sejak ratusan tahun dahulu dengan ditambah atau dimasukkan ke dalam makanan untuk membantu mengawet, menyedapkan, mencampurkan, memekatkan atau mewarnakannya. Contoh penggunaan aditif ialah garam untuk mengawet daging dan ikan serta rempah ratus untuk menyedapkan makanan, kuning telur untuk mengadunkan air dan minyak, cuka serta gula bagi

1 Garis Panduan Aditif Makanan yang Dibenarkan dalam Makanan di Malaysia di Bawah Peraturan-Peraturan Makanan 1985 (Peraturan 19, Peraturan-Peraturan Makanan 1985), Kementerian Kesihatan Malaysia, 1.

2 "Aditif Makanan", Jabatan Kimia Malaysia, dikemaskini 23 November 2017, dicapai 1 Disember 2017, http://www.kimia.gov. my/v3/ms/fungsi-bahagian/kesihatan-alam-sekitar/aditif-makanan. html 
mengawet buah-buahan dan membuat jeruk ${ }^{3}$. Perkembangan sains dan teknologi telah membantu mempelbagaikan penghasilan aditif makanan ${ }^{4}$. Penghasilan pelbagai aditif ini turut menyebabkan timbulnya keperluan penetapan halal haram aditif. Terdapat beberapa pandangan hukum Muzakarah Jawatankuasa Fatwa Majlis Kebangsaan yang telah diputuskan dan mempunyai kaitan dengan penetapan halal haram aditif. Sehubungan dengan itu, kajian ini dibuat untuk melihat sejauh mana pemakaian pendapat fiqh mazhab al-Shāfi ‘̄i yang menjadi asas pegangan masyarakat Islam di Malaysia dalam penetapan pandangan hukum tersebut. Ini akan membuktikan bagaimana kearifatan tempatan diaplikasikan secara berterusan oleh para ulama tempatan dalam mendepani isuisu pemakanan khususnya hukum halal haram aditif makanan di Malaysia.

\section{PELBAGAI JENIS ADITIF YANG DIBENARKAN DI MALAYSIA}

Secara umum, aditif makanan terdapat dalam dua bentuk iaitu natural dan sintetik. Aditif natural ialah aditif yang diekstrak dari suatu makanan untuk diletakkan di dalam makanan yang lain pula. Sintetik pula ialah aditif yang dibuat secara sintetik ${ }^{5}$. Keduadua bentuk aditif ini dapat dibahagikan kepada beberapa bahagian mengikut fungsi masing-masing sebagaimana Jadual 1 di bawah:

3 “Aditif Makanan - Apa yang perlu anda tahu?", Kementerian Kesihatan Malaysia, dicapai 7 Jun 2017, http://www.myhealth.gov. my/aditif-makanan-apa-yang-perlu-anda-tahu/.

4 "Overview of Food Ingredients, Additives \& Colors, Nov. 2004", U.S Food and Drug Administration (FDA), (revised 2010), dicapai 1 Julai 2017, https://www.fda.gov/food/ingredientspackaginglabeling/ foodadditivesingredients/ucm094211.htm.

5 Disediakan dari bahan kimia atau dari bahan tiruan dan bukan dari sumber semula jadi. 
Jadual 1: Jenis Aditif, Takrifan dan Contoh yang Dibenarkan di Malaysia $^{6}$

\begin{tabular}{|c|l|l|}
\hline Jenis Aditif & \multicolumn{1}{|c|}{ Takrifan } & \multicolumn{1}{c|}{$\begin{array}{c}\text { Contoh aditif } \\
\text { yang dibenarkan }\end{array}$} \\
\hline \multirow{3}{*}{$\begin{array}{c}\text { Bahan } \\
\text { Pengawet pengawet }\end{array}$} & $\begin{array}{l}\text { digunakan untuk } \\
\text { mengawal pertumbuhan } \\
\text { kulat, bakteria dan yis } \\
\text { bagi memanjangkan } \\
\text { jangka hayat }\end{array}$ & $\begin{array}{l}\text { Asid benzoik, asid } \\
\text { sorbik, sulphur } \\
\text { dioksida }\end{array}$ \\
& penyimpanan makanan & \\
\hline
\end{tabular}

6 "Aditif Makanan - Apa yang perlu anda tahu?", laman sesawang Kementerian Kesihatan Malaysia, dilayari pada 7 Jun 17, http:// www.myhealth.gov.my/aditif-makanan-apa-yang-perlu-anda-tahu/

a Pengawet (preservative) ialah apa-apa bahan yang apabila ditambah pada makanan boleh menyekat, merencat atau menahan proses penguraian, penapaian atau pengasidan makanan tersebut.

b Pewarna (colouring substance) ialah apa-apa bahan yang apabila ditambah pada makanan boleh memberi warna pada makanan tersebut.

c Bahan perisa (flavouring substance) digunakan untuk memberi dan mengekalkan rasa yang unik bagi sesuatu makanan.

d Penambah perisa (flavour enhancer) digunakan untuk menambah dan memperkuatkan rasa sesuatu makanan seperti Monosodium Glutamat (MSG).

- Antipengoksidaan (antioxidant) berfungsi untuk melambatkan proses pengoksidaan yang menyebabkan ketengikan dalam makanan.

f Kondisioner makanan (food conditioner). Ia merangkumi pengemulsi, agen antibuih, penstabil, pemekat, kanji ubahsuai, agen penggelan, pengawal asid, enzim, pelarut dan agen antipengerakan. Lihat Food Acts 1985, Part V, perkara 19, 20, 21, 22, 23, 24 dan 25. Lihat juga “Aditif Makanan - Apa yang perlu anda tahu?", laman sesawang Kementerian Kesihatan Malaysia, dicapai 7 Jun 17, http://www. myhealth.gov.my/aditif-makanan-apa-yang-perlu-anda-tahu/. Lihat juga "Aditif Makanan”, laman sesawang Jabatan Kimia Malaysia, dicapai 1 Disember 2017, http://www.kimia.gov.my/v3/ms/fungsibahagian/kesihatan-alam-sekitar/aditif-makanan.html. 


\begin{tabular}{|c|c|c|}
\hline Bahan pewarna $^{\mathrm{b}}$ & $\begin{array}{l}\text { Bahan pewarna } \\
\text { digunakan untuk } \\
\text { menjadikan makanan } \\
\text { lebih menarik dan } \\
\text { merangsang selera } \\
\text { makan }\end{array}$ & $\begin{array}{l}\text { Allura Red, } \\
\text { Sunset Yellow, } \\
\text { anthocyanin }\end{array}$ \\
\hline Bahan perisa $^{c}$ & $\begin{array}{l}\text { Bahan perisa digunakan } \\
\text { untuk memberi dan } \\
\text { mengekalkan rasa } \\
\text { yang unik bagi sesuatu } \\
\text { makanan }\end{array}$ & $\begin{array}{l}\text { Bahan perisa } \\
\text { aiskrim } \\
\text { (contohnya vanila, } \\
\text { strawberi, durian } \\
\text { dan lain-lain) } \\
\text { Bahan perisa } \\
\text { untuk minuman } \\
\text { (contohnya } \\
\text { jagung, oren, } \\
\text { anggur dan lain- } \\
\text { lain) }\end{array}$ \\
\hline $\begin{array}{l}\text { Penambah } \\
\text { perisa }^{\mathrm{d}}\end{array}$ & $\begin{array}{l}\text { Penambah perisa } \\
\text { digunakan untuk } \\
\text { menambah dan } \\
\text { memperkuatkan rasa } \\
\text { sesuatu makanan }\end{array}$ & $\begin{array}{l}\text { Monosodium } \\
\text { glutamat (MSG) }\end{array}$ \\
\hline Antipengoksida ${ }^{\mathrm{e}}$ & $\begin{array}{l}\text { Antipengoksidaan } \\
\text { berfungsi untuk } \\
\text { melambatkan proses } \\
\text { pengoksidaan yang } \\
\text { menyebabkan } \\
\text { ketengikan dalam } \\
\text { makanan }\end{array}$ & $\begin{array}{l}\text { Tokoferol } \\
\text { Asid askorbik, } \\
\text { Butylated } \\
\text { hydroxytoulene } \\
\text { (BHT) }\end{array}$ \\
\hline
\end{tabular}




\begin{tabular}{|c|c|c|}
\hline $\begin{array}{l}\text { Kondisioner } \\
\text { makanan }^{\mathrm{f}}\end{array}$ & $\begin{array}{l}\text { Kondisioner makanan } \\
\text { ditambah dalam } \\
\text { makanan untuk memberi } \\
\text { fungsi teknologi untuk } \\
\text { mendapatkan makanan } \\
\text { yang dihasratkan. } \\
\text { Jenis-jenis kondisioner } \\
\text { makanan yang } \\
\text { dibenarkan adalah: } \\
\text { Pengemulsi dan agen } \\
\text { antibuih. } \\
\text { Penstabil, pemekat, } \\
\text { kanji ubahsuai dan agen } \\
\text { penggelan. } \\
\text { Pengawal asid. } \\
\text { Enzim. } \\
\text { Pelarut. } \\
\text { Agen antipengerakan. }\end{array}$ & $\begin{array}{l}\text { Asid fosforik, } \\
\text { magnesium } \\
\text { karbonat, gum } \\
\text { xanthan, lecithin }\end{array}$ \\
\hline
\end{tabular}

Aditif yang digunakan di dalam sesuatu makanan boleh diketahui melalui penggunaan $\mathrm{kod}^{7}$ atau INS di hadapan dengan diikuti beberapa nombor berdasarkan penetapan di dalam International Numbering System (INS) untuk aditif makanan ${ }^{8}$. Jadual 2 di bawah menunjukkan kepada kod $\mathrm{E}$ atau INS mengikut kategori:

7 E bermaksud European Community (EU). E- Numbers ialah aditif yang dibenarkan untuk digunakan di Negara kesatuan Eropah.

8 International Numbering System ialah nombor tertentu yang digunakan untuk menunjukkan kepada jenis aditif dan funginya. Lihat "Class Names and The International Numbering System for Food Additives", International Alliance of Dietary/ Food Supplement Associations (IADSA), CAC/GL 36-1989, http://www.iadsa.org/ images/userfiles/International\%20Numbering\%20System_CAC_ GL\%2036-1989.pdf. Lihat juga, Handbook of Halal Food Additives (Kuala Lumpur: JAKIM, 2010), 1-2. 
Jadual 2: Kod E / INS dan Kelas ${ }^{9}$

\begin{tabular}{|c|l|}
\hline $\begin{array}{c}\text { Kod E-Number } \\
\text { INS }\end{array}$ & \multicolumn{1}{|c|}{ Kelas Aditif } \\
\hline $100-199$ & Pewarna \\
\hline $200-299$ & Pengawet \\
\hline $300-399$ & Antioksida, pengawal keasidan \\
\hline $400-499$ & $\begin{array}{l}\text { Kondisioner makanan (pemekat, penstabil, } \\
\text { pengemulsi) }\end{array}$ \\
\hline $500-599$ & Garam, regulator asid, agen penghalang kerak \\
\hline $600-699$ & Penambah perisa \\
\hline $700-799$ & Antimikrob \\
\hline $900-999$ & Lain-lain jujukan (Glazing agent, pemanis) \\
\hline $1000-1999$ & Pelbagai Aditif Makanan \\
\hline
\end{tabular}

Di Malaysia, kebenaran penggunaan pelbagai jenis aditif makanan di kawal oleh kementerian kesihatan melalui Akta Makanan 1983, Peraturan Makanan 1985 dan Garis Panduan Aditif Makanan yang Dibenarkan dalam Makanan di Malaysia di Bawah Peraturan - peraturan Makanan 1985, (Peraturan 19, PeraturanPeraturan Makanan 1985). Di bawah Peraturan 19, Peraturanperaturan Makanan (PPM) 1985, aditif makanan yang dibenarkan ditambah dalam makanan untuk jualan atau penggunaannya di Malaysia adalah seperti berikut:

i. Aditif makanan yang dibenarkan ditambah dalam makanan mengikut ketetapan tertentu yang dinyatakan secara spesifik di bawah PPM 1985; atau

ii. Aditif makanan yang dibenarkan ditambah adalah dalam kate-

9 Handbook of Halal Food Additives, 2. Lihat juga Farah Azura Khalil, "Aditif Makanan Daripada Perspektif Halal", Kementerian Kesihatan Malaysia, 29 Jan 2014, dicapai 8 Jun 2017, http://www.myhealth. gov.my/aditif-makanan-daripada-perspektif-halal/. 
gori makanan yang sepadan di bawah Codex Alimentarius ${ }^{10}$.

\section{PELBAGAI PANDANGAN HUKUM DI MALAYSIA YANG ADA KAITAN DENGAN ADITIF MAKANAN}

Muzakarah Jawatankuasa Fatwa Majlis Kebangsaan telah memutuskan beberapa pandangan hukum yang mempunyai kaitan dengan halal haram aditif makanan sebagaimana Jadual 3 di bawah:

Jadual 3: Pandangan Hukum Muzakarah Jawatankuasa Fatwa

Majlis Kebangsaan yang Ada Kaitan dengan Aditif Makanan ${ }^{11}$

\begin{tabular}{|c|l|l|}
\hline Bil. & Perkara /Tahun & \multicolumn{1}{c|}{ Pandangan Hukum } \\
\hline & & $\begin{array}{l}\text { Kordial yang mengandungi bahan cita } \\
\text { rasa (flavour) yang dimasukkan alkohol } \\
\text { untuk tujuan penstabilan adalah harus } \\
\text { (boleh) digunakan untuk tujuan minuman } \\
\text { sekiranya: } \\
\text { i) Alkohol itu bukan dihasilkan daripada } \\
\text { proses pembuatan arak. } \\
\text { ii) Kuantiti alkohol dalam citarasa (flavour) } \\
\text { itu adalah sedikit iaitu tidak memabukkan. }\end{array}$ \\
\hline $\begin{array}{l}\text { Alkohol sebagai } \\
\text { penstabil minuman } \\
\text { ringan / 1988 }\end{array}$ & & \\
\hline
\end{tabular}

10 Codex Alimentarius ialah standard, kod dan panduan makanan di peringkat antarabangsa untuk memastikan keselamatan dan kualiti makanan serta keadilan dalam pemerdaganagan. Lihat "About Codex", Codex Alimentarius Food Standards, dicapai 1 Julai 2017, http://www.fao.org/fao-who-codexalimentarius/about-codex/en/.

11 Jabatan Kemajuan Islam Malaysia, Kompilasi Pandangan Hukum Muzakarah Jawatankuasa Fatwa Majlis Kebangsaan Bagi Hal Ehwal Ugama Islam Malaysia (Kuala Lumpur: JAKIM, 2015), 170.

a Lihat Jabatan Kemajuan Islam Malaysia (2015) halaman 170.

b Ibid, 171.

c Ibid., 172-173.

d Ibid, 189.

e Ibid., 175-176.

f $\mathrm{v} / \mathrm{v}$ ialah volume/volume. $1 \% \mathrm{v} / \mathrm{v}$ bermaksud $1 \mathrm{ml} / 100 \mathrm{ml}$.

g Ibid., 178-179. Cochineal ialah sejenis kumbang betina.

h Ibid., 179. 


\begin{tabular}{|c|c|c|}
\hline 2. & $\begin{array}{l}\text { Keju sebagai bahan } \\
\text { makanan / } 1990^{\mathrm{b}}\end{array}$ & $\begin{array}{l}\text { Keju sebagai bahan makanan adalah harus } \\
\text { sama ada enzim yang digunakan sebagai } \\
\text { bahan campuran dalam pembuatan keju itu } \\
\text { diperolehi daripada tumbuhan atau kulat } \\
\text { atau binatang yang halal dan disembelih. }\end{array}$ \\
\hline 3. & $\begin{array}{l}\text { Hukum wine } \\
\text { vinegar (cuka } \\
\text { wain)/ } 2006^{c}\end{array}$ & $\begin{array}{l}\text { Haram menggunakan cuka wain yang } \\
\text { diproses dan dicampur dengan bahan- } \\
\text { bahan luar. Walau bagaimanapun, } \\
\text { sekiranya perubahan daripada cuka wain } \\
\text { kepada cuka berlaku dengan sendirinya, } \\
\text { maka ia adalah halal. }\end{array}$ \\
\hline 4. & $\begin{array}{l}\text { Hukum penggunaan } \\
\text { bulu binatang yang } \\
\text { halal dimakan } \\
\text { sebagai ramuan } \\
\text { makanan } / 2010^{\mathrm{d}} \\
\end{array}$ & $\begin{array}{l}\text { Penggunaan vitamin D3 yang terhasil } \\
\text { daripada bulu binatang yang halal dimakan } \\
\text { adalah harus sama ada ia diambil semasa } \\
\text { hidup atau selepas disembelih mengikut } \\
\text { hukum syarak. }\end{array}$ \\
\hline 5. & $\begin{array}{l}\text { Alkohol dalam } \\
\text { makanan, minuman, } \\
\text { pewangi dan ubat- } \\
\text { ubatan/ } 2011^{\mathrm{e}}\end{array}$ & $\begin{array}{l}\text { i) Setiap minuman arakadalahmengandungi } \\
\text { alkohol. Walau bagaimanapun, bukan } \\
\text { semua alkohol itu adalah arak. Alkohol } \\
\text { yang diperoleh dari proses pembuatan arak } \\
\text { hukumnya haram dan najis. } \\
\text { ii) Alkohol yang diperoleh bukan melalui } \\
\text { proses pembuatan arak hukumnya tidak } \\
\text { najis, tetapi haram (tidak boleh) diminum } \\
\text { dalam bentuk aslinya kerana ia adalah } \\
\text { racun dan boleh membunuh. } \\
\text { iii) Minuman ringan yang diproses/dibuat } \\
\text { bukan dengan tujuan untuk menghasilkan } \\
\text { arak dan mempunyai alkohol di bawah } \\
\text { aras } 1 \% \mathrm{v} / \mathrm{v}^{\mathrm{f}} \text { adalah harus diminum. } \\
\text { iv) Minuman ringan yang dibuat dengan } \\
\text { niat dan cara yang sama seperti proses } \\
\text { membuat arak, sama ada mengandungi } \\
\text { banyak atau sedikitalkohol atau alkoholnya } \\
\text { disuling adalah haram diminum. }\end{array}$ \\
\hline
\end{tabular}




\begin{tabular}{|c|c|c|}
\hline & & $\begin{array}{l}\text { v) Makanan atau minuman yang } \\
\text { mengandungi alkohol secara semula } \\
\text { jadi seperti buah-buahan, kekacang atau } \\
\text { bijirin serta perahannya, atau alkohol yang } \\
\text { terkandung itu terjadi secara sampingan } \\
\text { semasa proses pembuatan makanan atau } \\
\text { minuman adalah tidak najis dan harus } \\
\text { (boleh) dimakan/diminum. } \\
\text { vi) Makanan atau minuman yang } \\
\text { mengandungi bahan perisa atau pewarna } \\
\text { yang mengandungi alkohol untuk tujuan } \\
\text { penstabilan adalah harus digunakan } \\
\text { sekiranya alkohol itu bukan dihasilkan dari } \\
\text { proses pembuatan arak dan kuantiti alkohol } \\
\text { dalam produk akhir itu tidak memabukkan } \\
\text { dan kadar alkohol tidak melebihi 0.5\%. } \\
\text { vii) Ubat-ubatan dan pewangi yang } \\
\text { mengandungi alkohol sebagai bahan } \\
\text { pelarut adalah tidak najis dan diharuskan } \\
\text { sekiranya alkohol tersebut bukan diambil } \\
\text { melalui proses pembuatan arak. }\end{array}$ \\
\hline 6. & $\begin{array}{l}\text { Hukum bahan } \\
\text { pewarna cochineall } \\
2012^{\mathrm{g}}\end{array}$ & $\begin{array}{l}\text { i) Cochineal adalah jenis serangga yang } \\
\text { tidak membahayakan dan zat pewarna } \\
\text { yang dihasilkan daripada cochineal boleh } \\
\text { dimanfaatkan oleh manusia. Dari segi } \\
\text { perundangan negara, Peraturan-Peraturan } \\
\text { Makanan } 1985 \text { telah menetapkan pewarna } \\
\text { carmine yang diperolehi dan dihasilkan } \\
\text { daripada cochineal dibenarkan berdasarkan } \\
\text { Amalan Pengilangan Yang Baik (GMP). } \\
\text { ii) Muzakarah juga menegaskan bahawa } \\
\text { jumhur fuqaha' sepakat menetapkan } \\
\text { bahawa bangkai serangga yang darahnya } \\
\text { tidak mengalir adalah suci, dan pewarna } \\
\text { cochineal adalah diperolehi daripada } \\
\text { serangga cochineal yang telah mati dari } \\
\text { kategori binatang darahnya tidak mengalir. }\end{array}$ \\
\hline
\end{tabular}




\begin{tabular}{|l|l|l|}
\hline & $\begin{array}{l}\text { iii) Berdasarkan ketetapan tersebut, } \\
\text { Muzakarah bersetuju memutuskan } \\
\text { penggunaan bahan pewarna cochineal } \\
\text { dalam makanan, minuman dan barang } \\
\text { gunaan adalah diharuskan dan kadar } \\
\text { penggunaan yang dibenarkan adalah } \\
\text { mengikut ketetapan pihak Kementerian } \\
\text { Kesihatan Malaysia selagi mana ia tidak } \\
\text { mendatangkan kemudharatan. }\end{array}$ \\
\hline 7. & $\begin{array}{l}\text { Penggunaan mikro organisma terubahsuai } \\
\text { iaitu lactic acid bacteria yang diperolehi } \\
\text { daripada usus orang dewasa dalam } \\
\text { teknologi baru penghasilan monosodium } \\
\text { glutamat adalah dibenarkan kerana bakteria } \\
\text { yang digunakan tersebut dikategorikan } \\
\text { sebagai mutanajjis dan ianya telah melalui } \\
\text { glutamat (MSG) } \\
\text { menggunakan } \\
\text { mikro organisma } \\
\text { terubahsuai/ } 2014^{\mathrm{h}}\end{array}$ \\
$\begin{array}{l}\text { Pengasingan dan penyucian yang } \\
\text { tidak menyalahi hukum Syarak. }\end{array}$ \\
\hline
\end{tabular}

\section{ANALISIS PEMAKAIAN PENDAPAT FIQH MAZHAB AL- SHĀFI'I I DALAM PENETAPAN PANDANGAN HUKUM HALAL HARAM ADITIF MAKANAN}

Pendapat-pendapat fiqh dalam mazhab al-Shāfi'ī adalah pendapatpendapat Imam al-Shāfi ‘ī atau ulama’ dalam kalangan Shāfi'iyyah. Pendapat-pendapat tersebut ditetapkan berpandukan kepada metode ijtihad Imam al-Shāfi '⿳亠. Metode ijtihad beliau diasaskan di atas pelbagai dalil-dalil yang disepakati iaitu al-Quran, alSunnah, ijmak dan qiyas dan dalil-dalil lain seperti 'urf, istishab, mașlahah, istiqra' dan tahrim al-wasa 'il. ${ }^{12}$ Secara asasnya aditif sintetik adalah halal atas asas istishab bertepatan dengan kaedah fiqh al-asl al-ibahah ${ }^{13}$ (asal sesuatu adalah harus) kecuali ia memudaratkan atau semasa proses penghasilannya, terdapat

12 Lihat pelbagai kitab usul fiqh yang ditulis oleh al-Shāfi'iyyah seperti al-Mustasfa Min 'Ilm al-Usul oleh Al-Ghazzālī, al-Iḥkām fi Usūul alAhkkām oleh al-Amidi dan al-Bahr al-Muhit fi Ușül al-Fiqh oleh alZarkashi.

13 Al-Ṣuyūṭ̂i, 'Abd al-Rahmān bin Abū Bakr, al-Ashbah wa al-Nazā' 'ir (Bayrūt: Dār al-Kutub al-'Ilmiyyah, 1998), 1: 131. 
percampuran atau sentuhan dengan bahan najis. Hukum aditif natural pula bergantung kepada bahan asalnya atau bahan yang dicampurkan semasa proses penghasilannya sama ada ia najis ataupun tidak. Sekiranya bahan asalnya najis atau dicampurkan dengan najis, aditif itu adalah najis atas asas nas dan istishab bertepatan dengan kaedah fiqh al-asl baqa'ma kana 'ala ma kana ${ }^{14}$ (asal sesuatu itu kekal sebagaimana keadaan sebelumnya).

Bagi pandangan-pandangan hukum yang mempunyai kaitan dengan aditif makanan sebagaimana yang telah disenaraikan pada Jadual 3 di atas, analisis pemakaian pendapat mazhab al-Shāfi‘ dalam penetapannya adalah seperti berikut:

i) Pandangan hukum perkara 1 dan 5 berkaitan dengan penggunaan alkohol sebagai penstabil; alkohol terbahagi kepada dua iaitu alkohol yang terhasil daripada arak dan daripada bukan arak. Arak haram diminum secara ittifaq berdalilkan al-Quran. Walau bagaimanapun, terdapat perbezaan pendapat pada status kenajisannya. Dalam mazhab al-Shāfi ‘'i, arak adalah najis. ${ }^{15}$ Oleh itu, alkohol daripada arak adalah najis. Sebaliknya, alkohol yang dihasilkan bukan daripada arak tidak najis. Pada asasnya ia harus digunakan berdasarkan kepada kaedah alasl al-ibahah (asal sesuatu adalah harus) selagi mana ia tidak memudaratkan. Menurut al-Zarkashi, terdapat garis panduan yang masyhur dalam mazhab al-Shāfi'ī pada penetapan halal haram perkara-perkara yang tidak disebut oleh nas iaitu al-asl fi al-manafi' al-idhn, wa fi al-madarr al-man ${ }^{16}$ (asal dalam perkara yang memberi manfaat ialah keharusan dan asal dalam perkara yang mendatangkan mudarat ialah tegahan).

ii) Pandangan hukum perkara 2 berkaitan halal haram keju; dalam pembuatan keju, antara aditif yang digunakan ialah rennet. Ia adalah sejenis enzim yang dihasilkan daripada perut anak

14 Al-Zuhaylī, Muhammad, al-Qawa id al-Fiqhiyyah wa Tatbiqatuha fi al-Madhahib al-Arba 'ah (Damshiq: Dār al-Fikr, 2006), 1: 129.

15 Al- Nawawi, Yahya bin Sharaf, al-Majmu’ (Qāhirah: Dār al-Hadīth, 2010), 3: 546.

16 Al-Zarkashi, Muhammad bin Bahadur, al-Bahr al-Muhit fi Ușūl alFiqh (Kuwait: Wazarah al-Awqaf wa Shu'un al-Islāmiyyah, 1992), 16: 12 . 
lembu atau kambing. ${ }^{17}$ Terdapat di dalam rennet enzim renin. Fungsinya ialah untuk membantu proses pengumpalan susu menjadi keju. Daripada proses pengumpalan susu dan pengeringannya menjadi keju, terhasil pula aditif lain yang dikenali dengan whey. ${ }^{18}$ Ia digunakan dalam pelbagai makanan seperti susu bayi, biskut, ramuan kek dan pelbagai minuman. ${ }^{19}$ Oleh itu, hukum halal haram rennet memberikan kesan kepada hukum halal haram whey.

Terdapat perbezaan pendapat terhadap rennet yang diambil daripada binatang halal yang tidak disembelih mengikut syarak. Menurut mazhab Mālikī, ia adalah najis kerana berada dalam kantung yang najis ${ }^{20}$. Walau bagaimanapun, dalam mazhab Ḥanafi, Abu Hanifah berpendapat ia adalah suci dan boleh dimakan ${ }^{21}$. Menurut dua murid beliau pula, iaitu Abu Yusuf dan Muhammad, susu itu suci tetapi ia menjadi najis kerana terkena benda yang najis dan menjadi suci serta boleh dimakan selepas dibasuh pada bahagian luaran ${ }^{22}$. Di dalam mazhab Ḥanbalī pula, pendapat yang zahir menyatakannya sebagai najis kerana ia adalah cairan yang berada dalam bekas yang najis ${ }^{23}$.

17 "What Is Rennet", laman sesawang New England Cheese Making, dicapai 7 Julai 2017, http://www.cheesemaking.com/store/pg/106Rennet-FAQ.html.

18 "Rennin" laman sesawang World of Enzymes and Probiotics, 2013, dicapai 7 Julai17, http://worldofenzymes.info/enzymes-introduction/ rennin/. Whey adalah bahagian berair daripada susu yang dikeluarkan selepas keju mengental. Lihat Panduan Persatuan Pengguna Pulau Pinang, Halal Haram (Pulau Pinang: Persatuan Pengguna Pulau Pinang, 2006), 131.

19 Lihat Panduan Persatuan Pengguna Pulau Pinang, Halal Haram, 131-133.

20 Ibn Tahir, al-Habib, al-Fiqh al-Maliki wa Adillatuh (Bayrūt: Dār Ibn Hazm, 1998), 1: 33.

21 Al-Kasān̄i, 'Ala' al-Din Abu Bakr ibn Mas'ud, Bada' $i$ “ al-Sana 'i' (Qāhirah: Dār al-Hadīth, 2005), 6:209.

22 Ibid., 1:226.

23 Ibn Qudamah, 'Abd Allah bin Ahmad, al-Mughnī (Qāhirah: Dār alHadīth, 2004, 1:96 
Terdapat juga beberapa tulisan semasa yang berpendapat ia adalah halal ${ }^{24}$. Menurut mereka, rennet yang diambil daripada binatang yang tidak disembelih oleh syarak adalah halal. Hujah mereka hampir sama iaitu berdasarkan riwayat yang menyebut sahabat memakan keju yang dibuat oleh penduduk Iraq yang beragama Majusi ketika mereka membuka negara tersebut. Di samping itu terdapat riwayat yang menyebut Salman al-Farisi telah ditanya tentang lemak dan keju dan menjawab dengan berkata: Perkara yang halal adalah apa yang dihalalkan oleh Allah di dalam kitabNya dan yang haram ialah apa yang diharamkan oleh Allah

24 Hammad, Nazih, al-Mawad al-Muharramah wa al-Najasah (Dimashq: Dār al-Qalam) (2004), 59-60. Al-Muslim, Șālị̣ bin Muhammad, Tathir al-Najasat wa al-Intifa' biha (Riyad: Dār alFadilah, 2011), 219-221. Al-'Amudi, Fatimah Jamil, al-Ahkām alFiqhiyyah fi Qadaya al-Ghidha' wa al-Taghdhiyah ('Ammān: 'Imad al-Din li al-Nashr wa al-Tawzi‘, 2009), 105-107. 
di dalam kitabNya, dan apa yang didiamkan adalah dimaafkan ${ }^{25}$. Walau bagaimanapun, Ibn Qudamah ketika mengulas tentang riwayat yang mengatakan para sahabat memakan keju orang Majusi ketika memasuki Madain berpendapat bahawa terdapat ahli kitab di Madain. Orang-orang Majusi tidak menyembelih sendiri sebaliknya sembelihan binatang mereka dilakukan oleh ahli kitab. Walaupun ia adalah satu kemungkinan (ihtimal), tetapi ia adalah ihtimal yang mungkin ada dan asal sesuatu yang halal adalah kekal dan tidak gugur dengan syak. ${ }^{26}$

Dalam mazhab al-Shāfi‘ ${ }^{\top}$, rennet yang diambil daripada binatang halal yang tidak disembelih dengan sembelihan syarak adalah najis berpandukan kepada kaedah umum maytah yang

25 Matan hadis ini adalah seperti berikut:

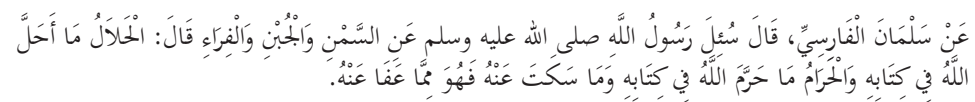

Riwayat Ibn Majah, Kitab al-At'imah, Bab Akl al-Jubn wa al-Samn, no. hadis 3367. Lihat al-Qazwini, Muhammad bin Zayd, Sunan Ibn Majah (Qāhirah: Dār Ibn al-Haitham, 2005), 4: 29. Hadis ini juga diriwayatkan oleh al-Tirmidhi, Kitab al-Libas, Bab Ma Ja'a fi Lubs al-Fira', no. hadis 1926. Menurut al-Tirmidhi, secara lebih asah, hadis ini berstatus mawquf. Lihat al-Tirmidhi, Sunan al-Tirmidhi, 457. Di samping itu, menurut 'Isam al-Sababati, Isnadnya da if kerana terdapat perawi yang bernama Saif bin Harun. Hadis ini juga tidak menunjukkan kepada keharusan apa yang ditanya, sebaliknya ia lebih menunjukkan kepada keperluan merujuk kepada al-Quran dalam penetapan suatu hukum. Sekiranya tiada nas al-Quran menunjukkan kepada hukum perlu pula dilihat kepada hadis. Apa yang tidak disebut adalah harus sebagai kemudahan kepada manusia melainkan ia mendatangkan mudarat. Lihat Muḥammad 'Abd al-Raḥmān alMubārakfurī, Tuḥfah al-Aḥwadhī. Qāhirah: Dār al-Hadīth, 2001), 5: 119-121. Menurut al-Sanadi, bukanlah yang dikehendaki oleh hadis ini untuk menerangkan hukum keharusan ketiga-ketiga perkara yang ditanya dengan diletakkan di bawah kategori al-maskut 'anh (perkara yang didiamkan), tetapi ia lebih kepada menerangkan garis panduan untuk mengetahui perkara yang halal dan haram secara umum. Lihat Hashiah al-Sanadi yang dicetak bersama dengan Sunan Ibn Majah yang terbitkan oleh Dār Ibn al-Haitham, 2005. Al-Qazwini, Sunan Ibn Majah, 4: 29.

Ibn Qudamah, al-Mughnī, 1:96. 
disebut oleh nas al-Quran. Ia merangkumi semua organ binatang yang tidak disembelih dengan sembelihan syarak. Oleh itu, apa sahaja yang datang dari binatang yang tidak disembelih dengan sembelihan syarak adalah najis. Menurut Imam al-Shāfi' $\overline{1}$, tidak halal daripada binatang yang telah mati melainkan kulit yang telah disamak $^{27}$. Menurut al-Māwardī pula, keseluruhan jasad haiwan yang mati adalah najis ${ }^{28}$.

iii) Pandangan hukum perkara 3 berkaitan cuka wain; cuka wain halal sekiranya perubahan berlaku secara semula jadi. Sebaliknya ia kekal najis sekiranya perubahan berlaku melalui usaha manusia. Penetapan ini bertepatan dengan pegangan Syafieyyah bahawa perubahan cuka yang dikira merubahnya menjadi halal hendaklah berlaku secara semula jadi. ${ }^{29}$

iv) Pandangan hukum perkara 4 berkaitan dengan Vitamin D3; ia diambil daripada bulu burung. Bulu binatang yang halal dimakan adalah suci dan boleh dimakan secara ijmak sekiranya tidak memudaratkan ${ }^{30}$. Walaupun begitu, dari sudut boleh dimakan ataupun tidak, ia kembali kepada membawa kebaikan atau kemudaratan. Asal adalah harus tetapi sekiranya mudarat, ia ditegah.

v) Pandangan hukum perkara 6 berkaitan aditif carmine atau E120; ia dihasilkan daripada sejenis kumbang yang terdapat di Mexico yang bernama cochineal. Ia termasuk di dalam kelompok serangga yang dikategorikan sebagai haiwan yang darahnya tidak mengalir. Dalam hal ini Imam al-Shāfi’ì berpendapat binatang seperti ini tidak boleh dimakan ${ }^{31}$ dan najis menurut qawl jadid tetapi suci menurut qawl qadim ${ }^{32}$.

27 Al-Māwardī, 'Ali bin Muhammad, al-Hāwwī al-Kabīr (Bayrūt: Dār al-Kutub al-'Ilmiyyah, 1994, 15: 162.

28 Ibid., 15:162.

29 Al-Nawawi, al-Majmu', 3:560-561

30 Al-Haitami, Ahmad bin Muhammad, Tuhfah al-Muhtaj (Bayrūt: Dār al-Kutub al-'Ilmiyyah, 2001), 1: 103.

31 Al-Shāfi' $\mathfrak{1}$, Muhammad bin Idris, al-Umm (Bayrūt: Dār al-Kutub al'Ilmiyyah, 2014) 2:378.

32 Al-Māwardī, al-Hā̄wī al-Kabīr, 1:321-322. 
Asas kepada tegahan memakan binatang seperti ini ialah 'urf iaitu jijik dan tidak dimakan oleh orang Arab. Menurut Imam al-Shāfi'î, salah satu ukuran penentuan tayyib dan khabith ialah sama ada ia dimakan atau tidak oleh orang Arab kerana ayat alQuran diturunkan kepada mereka secara langsung dalam bahasa mereka. Oleh itu, penetapan halal haram makanan bersesuaian dengan pengetahuan mereka tentang tayyibat dan khaba 'ith ${ }^{33}$. AlNawawi, al-Ramli dan al-Zuhaylī juga berpendapat al-hasyarat (serangga) semuanya jijik termasuklah khanafis (kumbang). Pengeculian hanya pada beberapa binatang sahaja seperti dab, yarbu' dan belalang ${ }^{34}$.

Apabila ditinjau kepada pendapat dalam mazhab-mazhab lain, terdapat pendapat dalam mazhab Mālikī yang mengatakan binatang seperti ini adalah suci dan halal. Antara asas pendapat mereka ialah umum firman Allah dalam surah al-An 'am ayat $145^{35}$ yang tidak menyebut binatang dari kategori ini tidak boleh dimakan di samping hadis Nabi SAW yang menyuruh ditenggelamkan lalat yang jatuh ke dalam air atau makanan.

Dalam mazhab Hanafī pula, bangkai binatang yang darahnya tidak mengalir adalah tidak najis. Hujah mereka juga berdasarkan kepada hadis Nabi SAW yang menyuruh menenggelamkan lalat di samping terdapatnya kesukaran untuk menjaga air atau makanan daripada binatang seperti ini ${ }^{36}$. Walaupun binatang dari kategori ini tidak najis tetapi ia tidak halal dimakan kerana termasuk di dalam khaba'ith ${ }^{37}$.

Dalam mazhab Hanbalī pula, binatang dari jenis ini tidak najis sekiranya ia tidak berasal daripada najis ${ }^{38}$. Walaupun tidak najis,

\footnotetext{
33 Al-Shāfi‘'̄i, al-Umm, 2: 377-378.

34 Al-Zuhaylī, Muhammad, al-Mu 'tamad fi Fiqh al-Shafi' $i$ (Dimashq: Dār al-Qalam, 2011), 2: 554. Al-Nawawi, al-Majmu', 10:25. AlRamlī, Shams al-Dīn Muḥammad Ibn Ab̄̄ al-'Abbās Aḥmad Ibn Hamzah Ibn Shihāb al-Dīn, Nihāyah al-Muhtāj (Bayrūt: Dār al-Fikr, 1984), 8: 155.

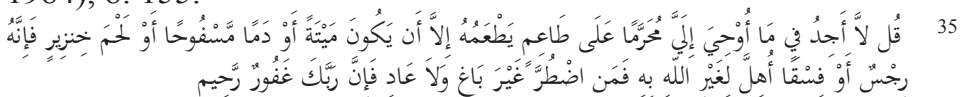

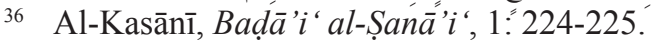

37 Ibid., 6: 187.

38 Ibn Qudamah, al-Mughnī, 1: 70-71.
} 
hukum memakannya adalah haram kerana termasuk di dalam kategori binatang yang khaba'ith dan tidak dimakan oleh orang $\mathrm{Arab}^{39}$.

Apabila ditinjau kepada pemakaian hukum pewarna carmine yang diambil daripada kumbang cochineal, didapati pandangan hukum dan fatwa ${ }^{40}$ di Malaysia memutuskannya halal. Hujah yang dikemukakan ialah persepakatan fuqaha' Hanafī, Mālikī dan Hanbalī bahawa binatang daripada jenis ini tidak najis di samping penggunaan serangga jenis ini sebagai sumber bahan pewarna tidak mendatangkan bahaya kepada manusia dan ia tidak mempunyai bahan yang memudaratkan. Walau bagaimanapun, pada pandangan penulis, pendapat tidak najis itu ialah pada bangkai binatang tersebut tetapi bukan bermakna jumhur fuqaha' berpendapat boleh dimakan kerana sebagaimana yang telah disebut sebelum ini, jumhur fuhaqa' daripada mazhab al-Shāfi 'ī, Hanafì dan Hanbalī mengatakan tidak boleh dimakan. Hanya mazhab Mālikī sahaja yang berpendapat ia boleh dimakan.

vi) Pandangan hukum pada perkara 7 pula berkaitan dengan perisa monosodium glutamat (msg). Hukumnya halal berdasarkan kaedah istishab iaitu suatu yang asalnya suci adalah kekal suci kecuali terdapat unsur percampuran dengan najis atau dibuat daripada najis atau mendatangkan kemudaratan kepada pengguna.

\footnotetext{
$39 \quad$ Ibid., 13:76.
}

40 Difatwakan di beberapa negeri seperti Selangor dan Pahang. Lihat Himpunan Keputusan Fatwa Negeri Pahang 2008-2014, Jabatan Mufti Negeri Pahang, 2014, 48. Lihat juga "Hukum Bahan Pewarna Cochineal: Kajian Semula Kadar Piawaian Yang Ditetapkan Oleh Muzakarah Jawatankuasa Fatwa Majlis Kebangsaan Bagi Hal Ehwal Agama Islam Malaysia", laman sesawang Jabatan Mufti Negeri Selangor, 2013, dicapai 30 Julai 2017, http:/www.muftiselangor. gov.my/fatwa-personalisation/fatwa-tahunan/keputusan-fatwaxwarta/2013/583-hukum-bahan-pewarna-cochineal-kajian-semulakadar-piawaian-yang-ditetapkan-oleh-muzakarah-jawatankuasafatwa-majlis-kebangsaan-bagi-hal-ehwal-agama-islam-malaysia. 
Satu perkara lagi yang dapat difahami secara tidak langsung daripada penetapan pandangan hukum ${ }^{41}$ di Malaysia ialah pendekatan pemakaian kaedah istihalah adalah berdasarkan pandangan al-Shāfi'iyyah. Secara zahirnya istihalah di sisi mazhab al-Shāfi'ī agak rigid berbanding mazhab Hanafī yang dikatakan lebih relevan dengan perkembangan industri masa kini. Namun para ulama tempatan masih cenderung mempertahankan penggunaan istihalah mazhab al-Shāfi' $\overline{1}$ khususnya dalam berhadapan dengan makanan yang berisiko tinggi berasaskan

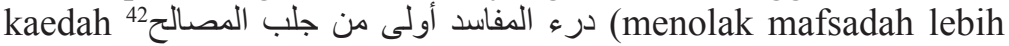
utama dari mencapai mașlahah) melalui pengamalan konsep ihtiyat (berhati-hati). Sehubungan dengan itu, pelbagai jenis aditif yang asalnya bersumberkan daripada najis dan diproses untuk menghasilkan suatu bahan yang lain seperti gelatin, renin ${ }^{43}$, pepsin $^{44}$ dan lain-lain adalah tidak halal.

Berdasarkan kepada analisis yang dibuat ke atas tujuh pandangan hukum Muzakarah Jawatankuasa Fatwa Majlis Kebangsaan yang mempunyai kaitan dengan penetapan halal haram aditif makanan di Malaysia, didapati penetapan hukum halal haramnya banyak dipengaruhi oleh pendapat fiqh dalam mazhab al-Shāfi'î. Selain membuktikan keunggulan mazhab alShāfi'ī dalam mendepani isu-isu semasa dan tempatan, ia juga secara langsung menggambarkan bagaimana kearifan para ulama tempatan dalam menyesuaikan pandangan mazhab tersebut dengan isu-isu semasa tanpa menidakkan pandangan mazhab lain

41 Contohnya ialah seperti pandangan hukum yang diputuskan oleh Muzakarah Jawatankuasa Fatwa kali ke 6, 24 September 1984 iaitu harus penggunaan gelatin dalam ubat adalah dalam keadaan darurat. Sekiranya telah ada bahan halal yang dapat menahan ubat dari cepat rosak, maka penggunaan gelatin (yang asal dari suatu yang haram) dalam ubat tidaklah lagi diharuskan. Lihat Kompilasi Pandangan Hukum Muzakarah Jawatankuasa Fatwa Majlis Kebangsaan Bagi Hal Ehwal Ugama Islam Malaysia, 105.

42 Al-Ṣuyūṭ̂, 'Abd al-Raḥmān bin Abū Bakr, al-Ashbah wa al-Naẓā'ir, 1: 188.

43 Terdapat di dalam pasaran, gelatin dan renin yang halal, iaitu yang asal daripada sumber yang halal.

44 Pepsin ialah sejenis aditif yang kebiasaannya diambil daripada perut babi. 
apabila ianya memenuhi kehendak semasa dan setempat. Justeru dalam penetapan isu hukum penggunaan pewarna carmine yang diambil daripada cochineal, pandangan mazhab Mālikī diambil kira sebagai faktor sokongan walaupun pada asasnya dari sudut lain ianya masih tidak terkeluar dari kerangka asal yang berasaskan kepada kaedah yang diterima pakai oleh ulama al-Shāfi'ī iaitu alasl fi al-manafi" al-idhn, wa fi al-madarr al-man'.

\section{KESIMPULAN}

Malaysia merupakan negara Islam yang masih menjadikan mazhab al-Shāfi'ī sebagai panduan utama dalam memutuskan sesuatu hukum dalam kalangan rakyatnya yang beragama Islam walaupun dari sudut individu sudah terdapat kalangan tertentu yang mengamalkan mazhab selain al-Shāfi‘ 1 . Dalam penetapan hukum halal haram aditif makanan di Malaysia, walaupun ianya bersifat subjektif kerana melibatkan isu-isu semasa dan perkembangan teknologi terkini, peranan dan pengaruh pendapat fiqh mazhab al-Shāfi' $\overline{1}$ masih mendominasi pandangan fiqh mazhab lain. Pendominasian ini tidak menggambarkan pengaruh mazhab al-Shāfi'ī berdasarkan sejarah dan latar berlakang umat Melayu semata-mata tetapi ia lebih membuktikan bagaimana keunggulan mazhab tersebut dan kebijaksanaan para ulama tempatan dalam menjustifikasikan kaedah dan manhaj mazhab al-Shāfi ‘̄ secara berterusan sehingga mampu menepati kehendak dan keperluan semasa umat Islam di Malaysia masa kini. Mengekalkan pemakaian mazhab al-Shāfi'ī sebagai mazhab yang dominan merupakan sebahagian dari warisan kearifan tempatan yang perlu diteruskan dan dipertahankan demi keutuhan dan penyatuan ummah di Malaysia.

\section{RUJUKAN}

"About Codex", Codex Alimentarius Food Standards, dicapai 1 Julai 2017, http://www.fao.org/fao-who-codexalimentarius/ about-codex/en/

"Aditif Makanan - Apa yang perlu anda tahu?", Kementerian Kesihatan Malaysia, dicapai 7 Jun 2017, http://www. myhealth.gov.my/aditif-makanan-apa-yang-perlu-andatahu/. 
"Aditif Makanan", Jabatan Kimia Malaysia, dikemaskini 23 November 2017, dicapai 1 Disember 2017, http://www. kimia.gov.my/v3/ms/fungsi-bahagian/kesihatan-alamsekitar/aditif-makanan.html.

"Class Names and The International Numbering System for Food Additives", International Alliance of Dietary/ Food Supplement Associations (IADSA), CAC/GL 36-1989, http://www.iadsa.org/images/userfiles/International\%20 Numbering\%20System CAC_GL\%2036-1989.pdf.

"Hukum Bahan Pewarna Cochineal: Kajian Semula Kadar Piawaian Yang Ditetapkan Oleh Muzakarah Jawatankuasa Fatwa Majlis Kebangsaan Bagi Hal Ehwal Agama Islam Malaysia", laman sesawang Jabatan Mufti Negeri Selangor, 2013, dicapai 30 Julai 2017,http://www.muftiselangor.gov. my/fatwa-personalisation/fatwa- tahunan/keputusan-fatwaxwarta/2013/583-hukum-bahan-pewarna-cochineal-kajiansemula-kadar-piawaian-yang-ditetapkan-oleh-muzakarahjawatankuasa- fatwa-majlis- kebangsaan-bagi-hal-ehwalagama-islam-malaysia.

"Overview of Food Ingredients, Additives \& Colors, Nov. 2004", U.S Food and Drug Administration (FDA), (revised 2010), dicapai 1 Julai 2017, https://www.fda.gov/food/ ingredientspackaginglabeling/foodadditivesingredie nts/ ucm 094211.htm.

"Rennin" laman sesawang World of Enzymes and Probiotics, 2013, dicapai 7 Julai17, http://worldofenzymes.info/ enzymes-introduction/rennin/

"What Is Rennet", laman sesawang New England Cheese Making, dicapai 7 Julai 2017, http://www.cheesemaking.com/store/ pg/106-Rennet-FAQ.html.

Al-'Amudi, Fatimah Jamil. al-Ahkām al-Fiqhiyyah fi Qadaya alGhidha' wa al-Taghdhiyah. 'Ammān: 'Imad al-Din li alNashr wa al-Tawzi‘, 2009.

Al-Haitami, Ahmad bin Muhammad. Tuhfah al-Muhtaj. Bayrūt: Dār al-Kutub al-'Ilmiyyah, 2001.

Al-Kasānī, 'Ala' al-Din Abu Bakr ibn Mas'ud. Bada 'i ' al-Sana ' $i$. Qāhirah: Dār al-Ḥadīth, 2005. 
Al-Māwardī, 'Ali bin Muhammad. al-Hāowī al-Kabīr. Bayrūt: Dār al-Kutub al-'Ilmiyyah,1994.

Al-Muslim, Șāliḥ bin Muhammad. Tathir al-Najasat wa al-Intifa ' biha. Riyad: Dār al-Fadilah, 2011.

Al-Nawawi, Yahya bin Sharaf. Al-Majmu'. Qāhirah: Dār alHadith, 2010.

Al-Qazwini, Muhammad bin Zayd. Sunan Ibn Majah. Qāhirah: Dār Ibn al-Haitham, 2005.

Al-Ramlī, Shams al-Dīn Muḥammad Ibn Abī al-'Abbās Aḥmad Ibn Hamzah Ibn Shihāb al-Dīn, Nihāyah al-Muhtâjj. Bayrūt: Dār al-Fikr, 1984.

Al-Shafi‘i, Muhammad bin Idris. Al-Umm. Bayrūt: Dār al-Kutub al-'Ilmiyyah, 2014.

Al-Ṣuyūṭī, 'Abd al-Raḥmān bin Abū Bakr. Al-Ashbah wa alNazā 'ir. Bayrūt: Dār al-Kutub al-'Ilmiyyah, 1998.

Al-Tirmidhi, Muhammad bin 'Isa. Sunan al-Tirmidhi. Qāhirah: Dār Ibn al-Haitham, t.t.

Al-Zarkashi, Muhammad bin Bahadur. Al-Bahr al-Muhit $f_{i}$ Usūl al-Fiqh. Kuwait: Wazarah al-Awqaf wa Shu'un alIslāmiyyah, 1992.

Al-Zuhaylī, Muhammad, al-Qawa id al-Fiqhiyyah wa Tatbiqatuha fi al-Madhahib al-Arba' ah (Dimashq: Dār al-Fikr, 2006).

Al-Zuhaylī, Muhammad. Al-Mu'tamad fi Figh al-Shafi'i. Dimashq: Dār al-Qalam, 2011.

Farah Azura Khalil, "Aditif Makanan Daripada Perspektif Halal”, Kementerian Kesihatan Malaysia, 29 Jan 2014, dicapai 8 Jun 2017, http://www.myhealth.gov.my/aditif- makanandaripada-perspektif-halal/

Food Acts 1985, Part V, perkara 19, 20, 21, 22, 23, 24 dan 25.

Garis Panduan Aditif Makanan yang Dibenarkan dalam Makanan di Malaysia di Bawah Peraturan -Peraturan Makanan 1985, Kementerian Kesihatan Malaysia.

Hammad, Nazih. al-Mawad al-Muharramah wa al-Najasah. Dimashq: Dār al-Qalam, 2004. 
Handbook of Halal Food Additives. Kuala Lumpur: JAKIM, 2010.Himpunan Keputusan Fatwa Negeri Pahang 20082014. Pahang: Jabatan Mufti Negeri Pahang, 2014.

Ibn Qudāmah, 'Abd Allah bin Ahmad. al-Mughnī. Qāhirah: Dār al-Hadīth, 2004.

Ibn Tahir, al-Habib. Al-Fiqh al-Mālikī wa Adillatuh. Bayrūt: Dār Ibn Hazm, 1998.

Kompilasi Pandangan Hukum Muzakarah Jawatankuasa Fatwa Majlis Kebangsaan Bagi Hal Ehwal Ugama Islam Malaysia. Kuala Lumpur: JAKIM, 2015.

Muḥammad 'Abd al-Raḥmān al-Mubārakfurī, Tuhfah al-Aḥwadhī. Qāhirah: Dār al-Hadìth, 2001.

Panduan Persatuan Pengguna Pulau Pinang, Halal Haram. Pulau Pinang: Persatuan Pengguna Pulau Pinang, 2006. 
Jurnal Fiqh, Vol. 16 No. 1 (2019) 105-128 